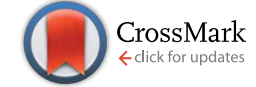

Cite this: RSC Adv., 2017, 7, 6046

Received 13th November 2016 Accepted 16th December 2016

DOI: 10.1039/c6ra26737h

www.rsc.org/advances

\section{Two decades of new drug discovery and development for Alzheimer's disease $\uparrow$}

\author{
Zhidong Liu, ${ }^{a}$ Aihua Zhang, ${ }^{a}$ Hui Sun, ${ }^{a}$ Ying Han, ${ }^{a}$ Ling Kong ${ }^{a}$ and Xijun Wang ${ }^{* a b}$ \\ Alzheimer's disease is a progressive and irreversible neurodegenerative disease, associated with a decreased \\ cognitive function and severe behavioral abnormalities. Due to its complex pathophysiological \\ characteristics, complicated interactions with a large number of genes and proteins, there is still no effective \\ drug treatment of the disease. Amyloid cascade aggregation of senile plaques and hyperphosphorylation of \\ Tau protein to form neurofibrillary tangles are the main pathological features of Alzheimer's disease, other \\ mechanisms, such as oxidative stress, lack of central cholinergic neurotransmitters, inflammatory reaction \\ and toxic metal ions have also been involved. The purpose of this review is to briefly introduce the progress \\ of the development of the therapeutic agents based on their main mechanisms of action.
}

\section{Introduction}

Alzheimer's disease (AD), a progressive and irreversible neurodegenerative disease and complicated multi-factorial disorder, is one of the most common forms of dementia. ${ }^{1}$ It is estimated that there are more than 35 million $\mathrm{AD}$ patients worldwide. $\mathrm{AD}$ has been recognized as one of the most difficult medical problems with heavy social and economic costs. ${ }^{2}$ So far, there has been no effective drug or treatment to prevent or reverse the progression of the disease. $\mathrm{AD}$ is characterized by progressive memory loss, cognitive impairment and severe behavioral abnormalities. The major pathological features of $\mathrm{AD}$ are extracellular aggregation of amyloid $\beta$ peptide (A $\beta)$ forming senile plaques (SP), the deposits of intracellular neurofibrillary tangles (NFTs). ${ }^{3}$ Although there is extensive study on the pathogenesis of $\mathrm{AD}$, the exact mechanism of $\mathrm{AD}$ is still unknown due to its complex pathophysiological characteristics. Several mechanisms have been proposed attempting to explain the pathogenesis of the disease, the amyloid $\beta$ (A $\beta)$ cascade, ${ }^{4}$ the hyperphosphorylated Tau protein,${ }^{5}$ oxidative stress, ${ }^{6}$ deficiency of central cholinergic neurotransmitter, ${ }^{7}$ inflammation $^{8}$ and toxic metal ions ${ }^{9}$ have been involved. Although the pathogenesis of the disease is not clear, new agents associated with the pathological changes of the disease are significantly developed.

${ }^{a}$ National TCM Key Laboratory of Serum Pharmacochemistry, Sino-US Chinmedomics Technology Cooperation Center, Chinmedomics Research Center of TCM State Administration, Laboratory of Metabolomics, Key Pharmacometabolomics Platform of Chinese Medicines, Department of Pharmaceutical Analysis, Heilongjiang University of Chinese Medicine, Heping Road, Harbin, China. E-mail: xijunwangls@ 126.com; Fax: +86-451-82110818; Tel: +86-451-82110818

${ }^{b}$ State Key Laboratory of Quality Research in Chinese Medicine, Macau University of Science and Technology, Avenida Wai Long, Taipa, Macau

$\dagger$ Electronic supplementary information (ESI) available. See DOI: $10.1039 /$ c6ra26737h
The purpose of this review is to briefly introduce the progress of the development on the therapeutic agents based on their main mechanisms of action, which hoping to promote the development of the next generation of $\mathrm{AD}$ therapeutic drugs.

\section{The pathogenesis}

\subsection{Amyloid cascade hypothesis}

One of the main pathological features of $\mathrm{AD}$ is the formation of senile plaques (SP), which caused by amyloid beta (A $\beta)$ deposition. Normally, $A \beta$ is soluble small peptides, which is produced by cleavage of the amyloid precursor protein (APP) by the action of $\alpha$ secretase, $\beta$-secretase and $\gamma$-secretase. ${ }^{10}$ The imbalance between $\beta$-amyloid $(\mathrm{A} \beta)$ production and clearance leads to various types of toxic oligomeric, namely protofibrils, fibrils and plaques depending upon the extent of oligomerization. ${ }^{11}$ The reason of the formation of $A \beta$ is still unknown, but the sequence, concentration and conditions of stability of $A \beta$ are important factors. ${ }^{12}$ Some studies suggested that neurotoxicity required assembly of the peptide into oligomers, ${ }^{13}$ and other evidences suggested that soluble oligomers forms of $A \beta$ could produce more neurotoxicity. ${ }^{14}$ A thorough study shows that amyloid toxicity associated with both protein-specific and conditional-determined by the function of vascular endothelial growth factor receptor 2 (VEGFR2) loss, which is essential for target protein in a biological context. ${ }^{15}$ A recent work systematic reviewed of the 25 years of the development and latest findings of the amyloid hypothesis, and elaborated the features of its cell biology and genetics. Suggesting that amyloid dyshomeostasis has emerged as the most extensively validated and compelling therapeutic target. ${ }^{16}$

\subsection{Hyperphosphorylated Tau protein}

The neurofibrillary tangles (NFTs) formed by hyperphosphorylated Tau protein are another major pathological 
feature of $\mathrm{AD}$. Tau protein belongs to the family of microtubuleassociated proteins, mainly existing in the axon, ${ }^{\mathbf{1 7}}$ and its main function is to maintain the stability of microtubules. ${ }^{18}$ There are several phosphorylation sites on Tau protein, compared with the mature nerve cells, the Tau protein in the growing nerve cells is more likely to be phosphorylated. ${ }^{19}$ Normally, the phosphorylation and dephosphorylation of Tau protein maintain a dynamic balance, but when the hyperphosphorylated Tau protein aggregates to form a double-helix fiber, it loses the function of connecting and stabilizing microtubules, which leads to the death of neurons. ${ }^{20,21}$ There has been a long-standing debate over the temporal mechanistic relationship between the two major pathological features of $\mathrm{AD}$, and evidence reports that soluble amyloid beta protein dimers induces Tau protein hyperphosphorylation and neurodegeneration. ${ }^{22}$

\subsection{Oxidative stress hypothesis}

Reactive oxygen species (ROS) and reactive nitrogen species (RNS) are produced in many normal and abnormal processes in humans, they play a dual role as both beneficial function of numbers of cellular signaling pathways and deleterious process that can lead to damage of cellular structures (including cell membrane, lipid, protein, and DNA). ${ }^{23}$ The high oxygen consumption of the brain, which utilizes $20 \%$ more oxygen than other mitochondrial respiratory tissues, means that the brain is more vulnerable to oxidative stress. ${ }^{24}$ Neuron is the basic function unit of the brain, which contains a large number of polyunsaturated fatty acids. It can interact with ROS, leading to the lipid peroxidation reaction and molecular apoptosis, ${ }^{25}$ in addition, less glutathione in neurons is also one of the causes of oxidative stress injury. ${ }^{26}$

\subsection{Cholinergic hypothesis}

Bartus et al. proposed the cholinergic hypothesis that dysfunction of cholinergic activity in the brain of healthy elderly and dementia patients may play a role in the loss of memory and related cognitive impairment, so reconstruction of cholinergic function may be able to reduce the serious lack of cognitive function. ${ }^{27}$ The activity of the cholinergic system was evaluated by choline acetyl transferase (ChAT) and acetylcholinesterase (AChE) etc. ${ }^{28}$ The study showed that the Ach, ChAT and AChE in the brain of $\mathrm{AD}$ patients showed a continuous decline. ${ }^{29}$ Acetylcholine (ACh) is neurotransmitters regulating cognitive performance and learning and memory process, ${ }^{30}$ synthesized by acetyl CoA and choline under the catalysis of ChAT, ACh and its receptor (AChR) combined with transfer nerve impulses, AChE hydrolyzed into acetic acid and choline. Acetylcholine established synaptic contacts in networks of brain cells to remodelling of the cerebral cortical circuits, which will subserve complex cognitive functions. ${ }^{31}$

\subsection{Inflammatory hypothesis}

Inflammatory responses in the brain is another pathological characteristic in $\mathrm{AD}$, usually chronic inflammation, main characteristics for a large numbers of mononuclear leucocytes and macrophages in the central nervous system, such as small glial cells. ${ }^{32}$ Compared with normal subjects, acute phase proteins and proinflammatory cytokines over expression in AD patients brain tissues. ${ }^{3,34}$ Microglia and astrocytes are the main causes of the inflammatory response, the activated cells produce proinflammatory mediators, such as interleukin 1 beta (IL-1) and interleukin 6 (IL-6) and tumor necrosis factor (TNF alpha), chemotactic factor interleukin 8 (IL-8), macrophage inflammatory protein-1, prostaglandins, leukotrienes, coagulation factor, protease, protease inhibitors $;^{35,36}$ The production of these substances can kill the neighboring neurons. ${ }^{37}$

\subsection{Metal ion hypothesis}

Metal ions play an important role in the maintenance of homeostasis, ${ }^{38}$ and the relationship between metal ions and neurodegenerative diseases has attracted much attention in recent years. ${ }^{39,40}$ The brain is rich in metals that act as essential cofactors in metalloproteins to participates in the process of metabolism, ${ }^{\mathbf{4 1}}$ the concentration of metal ions in the brain is tightly regulated through the blood brain barrier, when the blood brain barrier of metal ion regulation system degradation, ${ }^{42}$ metal ion transport dysfunction, metal ions (iron, copper, manganese, aluminum, zinc, etc.) begin to affect the oxidative stress response of mitochondria and the wrong folding proteins, and ultimately lead to neurodegeneration. ${ }^{\mathbf{4 3 , 4 4}}$ Studies have indicated that aluminum, zinc, copper and iron can lead to changes in the conformation of the $A \beta$ protein. ${ }^{45}$ Aluminum can lead to the accumulation of $A \beta$ and Tau protein, ${ }^{\mathbf{4 6}}$ aluminum and copper are involved in the process of the development of nerve inflammation. ${ }^{47}$ The increased levels of iron, aluminum and copper in the aged human brain may reflect the relationship between age and neurodegenerative diseases. $^{48}$

\section{Cholinergic drugs}

Drachman and Leavitt suggested that memory was associated with the cholinergic system and was age dependent, ${ }^{49}$ and Bartu $^{27}$ proposed Alzheimer's cholinergic hypothesis on which the development of cholinergic inhibitors is mainly based. ${ }^{\mathbf{5 0}}$ Study suggested that the acetylcholine (ACh), neurotransmitters regulating cognitive performance and learning and memory process, ${ }^{51}$ in the brain of $\mathrm{AD}$ patients showed a continuous decline. ${ }^{52}$ The loss of cholinergic function is related to cognitive impairment and behavioral disorder, and these symptoms can be improved by acetylcholinesterase (AChE) inhibitors or by modulating other cholinergic receptors, such as muscarinic and nicotinic ACh receptors. In 1993, tacrine was first approved by FDA to treat with mild to moderate $\mathrm{AD},{ }^{53,54}$ in addition three cholinesterase inhibitors were followed: donepezil (1996), ${ }^{55,56}$ rivastigmine $(2000)^{57}$ and galantamine (2001). ${ }^{58}$ However, other drugs have not been approved yet, including AChE inhibitors velnacrine, physostigmine, eptastigmine, metrifonate etc. ${ }^{59}$ muscarinic receptor agonists cevimeline (AF102B), milameline, sabcomeline (SB 202026), talsaclidine, xanomeline and alvameline (LU 25-109). ${ }^{60}$ In addition to the cholinesterase inhibitor, memantine, a $N$-methyl D-aspartate (NMDA) receptor 
<smiles>Nc1c2c(nc3ccccc13)CCCC2</smiles><smiles>COc1cc2c(cc1OC)C(=O)C(CC1CCN(Cc3ccccc3)CC1)C2</smiles>

Tacrine

Donepezil<smiles>CCN(C)C(=O)Oc1cccc([C@@H](C)N(C)C)c1</smiles>

Rivastigmine<smiles>COc1ccc2c3c1O[C@H]1C[C@@H](O)C=C[C@]31CCN(C)C2</smiles>

Galantamine

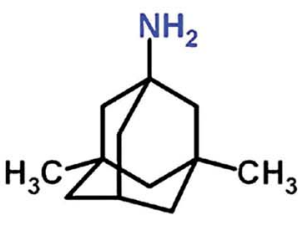

Memantine

Fig. 1 Five medicines approved by the US FDA for treatment in Alzheimer's disease.

antagonist which acts on the glutamatergic system, is another FDA approved for treatment of moderate-to-severe AD drugs. ${ }^{61,62}$ Besides the drugs approved by FDA, there has still been progress in development of cholinergic drugs in clinical trials as well as patented lead compounds. Fig. 1 and Table S1 $\uparrow$ show five drug approved by the US FDA for treatment in AD.

Huperzine A, an alkaloid derived from the Chinese herb Huperzia serrata, acts as a selective inhibitor of acetylcholinesterase, which has a mechanism of action similar to donepezil. ${ }^{63}$ Huperzine A has shown promising effects on the treatment of Alzheimer's disease, ${ }^{64}$ including improvement of cognitive function, daily living activity, and global clinical assessment. ${ }^{65}$ However, one trial demonstrated no significant change in cognitive function as measured by Alzheimer's disease Assessment Scale-Cognitive Subscale (ADAS-Cog) ${ }^{66}$ and clinical data are limited by poor methodological quality. ${ }^{67}$ Pro-drug of huperzine A, named ZT-1, derived from natural product, is a potent and selective AChE inhibitor. The results from the Phase I clinical trials showed that ZT-1 has an admirable pharmacokinetic with a rapid absorption and a wide distribution in human. ${ }^{68}$

Physostigmine, originally having been extracted from calabar beans, is an AChE inhibitor, but it has limited treatment effects and serious side effects. ${ }^{69}$ The (-)-phenserine, a derivative of physostigmine, is an AChE inhibitor that has an effect on cognitive improvement. It also can reduce the translation of APP to reduce A $\beta$ concentrations, suggesting (-)-phenserine may be a promising multitarget drug of $\mathrm{AD}^{\mathbf{7 0}}$

Memogain (Gln-1062), an inactive pro-drug of galantamine, liberates galantamine on cleavage by a carboxylesterase in the brain. Memogain has more than 15 -fold higher bioavailability in the brain than the same doses of galantamine due to the more hydrophobic characteristics. Memogain may represent a valuable drug with higher potency in enhancing cognition for $\mathrm{AD}$ treatment, a significantly lower plaque density in the brain, and much lesser gastrointestinal side effects. ${ }^{71,72}$

Ladostigil is a novel multitarget drug combined with acetylcholine-butyrylcholinesterase cholinesterase inhibitor and brain selective monoamine oxidase A and B inhibitor. It can relieve scopolamine-induced impairment in spatial memory, and increase brain cholinergic activity in rat. Furthermore, it was proved to possess anti-apoptotic and neuroprotective including the regulation of APP process, activation of protein kinase $\mathrm{C}$ and mitogen-activated protein kinase signaling pathways. ${ }^{73}$ NGX267 (AF267B), as M1-selective muscarinic agonists, can enhance the cognitive ability ${ }^{74}$ In AD transgenic mice, it also reduced $A \beta 1-42$ and Tau hyperphosphorylation in the cortex and hippocampus, presenting an unique beneficial effects on therapy in AD. ${ }^{75}$ EVP-6124 is a partial, selective agonist of the $\alpha-7$ nicotinic acetylcholine receptor ( $\alpha 7$-nAChR) with highly CNS-penetrant. It can improve cognitive deficits by boosting the ACh response of $\alpha 7$ nAChRs. EVP-6124 moved into Phase III for AD, supporting a new therapeutic strategy for the treatment of cognitive impairment. ${ }^{76}$ Additionally, GTS- 21 is a selective agonist of the $\alpha 7$ nicotinic receptor, showed promising characteristics during Phase II clinical trial. ${ }^{77}$ Fig. 2 and Table S2 $\uparrow$ show cholinergic inhibitors in clinical trials.

\section{Amyloid-targeted therapies}

\subsection{Decreasing $\mathbf{A} \boldsymbol{\beta}$ production}

4.1.1. $\quad \beta$-Secretase inhibitors. LY2811376 is the first orally non-peptidic small-molecule BACE1 inhibitor with satisfactory pharmacokinetic and pharmacodynamic properties from

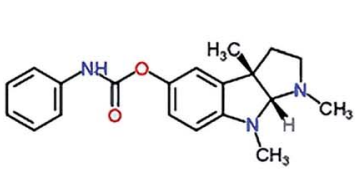

(-)-Phenserine

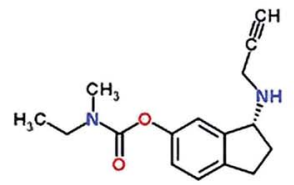

Ladostigil

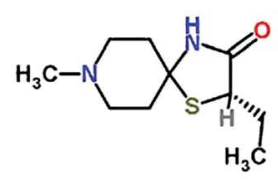

AF267B

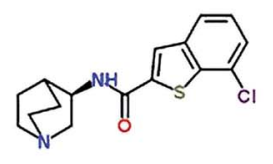

EVP-6124

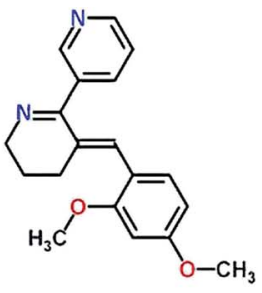

GTS-21

Fig. 2 Cholinergic inhibitors in clinical trials. 
preclinical animal models to man. ${ }^{78}$ It can penetrate the blood brain barrier, and showed long-lasting effect on reducing the level of $A \beta$ in healthy volunteers. However, clinical development was stopped according to a chronic non-target-associated toxicology. LY2886721, next-generation orally available BACE1 inhibitor with agreeable drug properties, reduce the concentrations of cerebral A $\beta 40, A \beta 42$ and SAPP- $\beta$ with safety and good tolerability. ${ }^{79,80}$ Unfortunately, it was terminated because of abnormal liver biochemical tests. MK-8931 developed by the pharmaceutical company Merck, is a BACE1 inhibitor tested for the treatment of $\mathrm{AD}$ in Phase I clinical trial. It can significantly reduce the levels of CSF A $\beta$ in a dose-dependent and sustained way. ${ }^{81}$ MK-8931 also reduces the concentration of CSF A $\beta$ in patients with mild-to-moderate $\mathrm{AD} .^{82}$ And further research shows that MK-8931 elicits few adverse effects previously ascribed to BACE inhibition, different doses are well tolerated and reduce CNS $\beta$-amyloid in both healthy human subjects and $\mathrm{AD}$ patients. The human data are suitable for the amyloid pathway model and provide a meaningful guidance for further experiments. ${ }^{83}$ E2609, an orally available BACE1 inhibitor, showed dose-dependent reductions of $A \beta$ concentrations in CSF and/or plasma in a single oral ascending dose study and multiple oral ascending dose study respectively. Phase 2 clinical trial of E2609 is planned by Eisai. ${ }^{84,85}$ Fig. 3 and Table S3 $\uparrow$ show $\beta$-secretase inhibitors in clinical trials.

4.1.2. $\gamma$-Secretase inhibitors and modulators. Semagacestat (LY-450139) is a $\gamma$-secretase inhibitor in the aim to treat AD. It can lower $\mathrm{A} \beta$ concentrations in the plasma and cerebrospinal fluid with a dose-dependent manner. ${ }^{86}$ However, the trial was terminated owning to severe adverse effects and worsen cognition performance compared to placebo group. ${ }^{87}$ It is believed that inhibiting $\gamma$-secretase may disturb Notch signaling proteins and other cell surface receptors. ${ }^{88}$ Avagacestat (BMS708163) is also a $\gamma$-secretase inhibitor with Notch-sparing effect. Nevertheless, avagacestat did not demonstrate obvious efficacy from Phase II trials in MIC. ${ }^{89}$ Begacestat (GSI-953) is a thiophene sulfonamide $\gamma$-secretase selectively inhibitor which inhibits cleavage of APP over Notch. ${ }^{90}$ The compound has shown promise in recent Phase I clinical trials. ${ }^{91}$

NIC5-15 is a natural compound acted as a Notch-sparing $\gamma$ secretase inhibitor and an insulin sensitizer. The compound can improve cognitive function through multiple mechanisms including reduce $A \beta$ production by modulating $\gamma$-secretase. ${ }^{92}$ The result shows that NIC5-15 is safe and has good tolerability and further feasibility trials are needed..$^{93}$ CHF5074, a new microglial modulator, reduces brain $\mathrm{A} \beta$ burden to enhance spatial memory cognitive in transgenic mice of AD model. ${ }^{94}$ CHF5074 shows dose-dependent effects in central nervous system and well tolerated and safety in mild-to-moderate patients. ${ }^{95}$ E2012 is also a novel $\gamma$-secretase modulator which decreases the concentration of $A \beta 40$ and $A \beta 42$ in rat in a dosedependent manner, and without affecting Notch cleavage. ${ }^{96}$ Fig. 4 and Table S4† show $\gamma$-secretase inhibitors and modulators in clinical trials.

\subsection{Promoting $\mathrm{A} \beta$ clearance}

4.2.1. Active AD immunotherapy. AN-1792 was the first fulllength $A \beta 1-42$ active vaccine used in clinical trial. Although the trial was terminated after $6 \%$ of the participants developed severe side effect, it provided an important proof of concept. ${ }^{97}$ CAD106 is the second-generation active immunotherapy vaccine that comprises $A \beta 1-6$ peptide. The study suggests that CAD106 can reduce AB accumulation and lead to acceptable antibody response with a safe and tolerance manner in Phase II trials. ${ }^{98} \mathrm{ACI}-24$ is a Aß1-15 liposome-based vaccine that can restore the memory defect and reduce plaque in transgenic mice. A phase I/II clinical trial is currently ongoing for investigating the safety and efficacy of mild-to-moderate $\mathrm{AD}$ patients. ${ }^{99}$ UB-311 is synthetic peptides, consisting of UBITh helper T-cell epitopes and coupled to the $\mathrm{A} \beta 1-14$ peptide. ${ }^{100} \mathrm{~A}$ phase $1 \mathrm{clin}$ ical trial of UB-311 has successfully completed, illustrating safety and tolerability. ${ }^{101}$ In addition, Phase 2 clinical trials are being prepared.

Other ongoing trails include ACC-001, V950, Lu AF20513 and AD02 as well. ACC-001 (Vanutide cridificar), an A $\beta 1-7 / Q s 21$ adjuvant immunotherapeutic vaccine, was evaluated in phase $2 \mathrm{a}$ and results came out with safety profile in mild-to-moderate AD patients. ${ }^{102}$ V950, multivalent A $\beta$ peptide/ISCOMATRIX ${ }^{\text {TM }}$ adjuvant, aimed to produce $A \beta$ antibodies to recognize pyroglutamate-modified and other N-terminally truncated $A \beta$ fragments. A phase 1 has been completed and further studies were discontinued. ${ }^{103}$ Lu AF20513 was developed by Lundbeck A/S (Valby, Denmark) according to A $\beta 1-12$ peptide replaced with two foreign T-helper epitopes from tetanus toxoid. It is currently being tested in preclinical trail. ${ }^{104}$ Additionally, AD02 is an amyloid-beta $(A \beta)$-targeting vaccine to elicit anti- $\mathrm{A} \beta$ antibodies, and phase II study was finished. ${ }^{105}$ DNA amyloid-beta protein immunotherapy is currently being investigated in

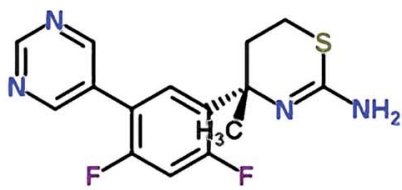

LY2811376

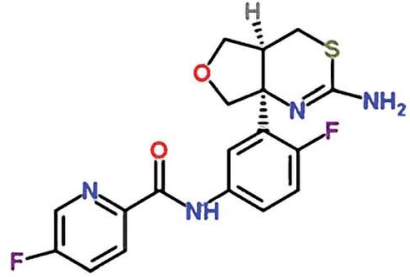

LY2886721

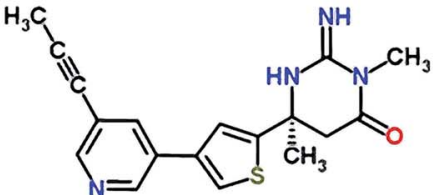

MK-8931

Fig. $3 \quad \beta$-Secretase inhibitors in clinical trials. 


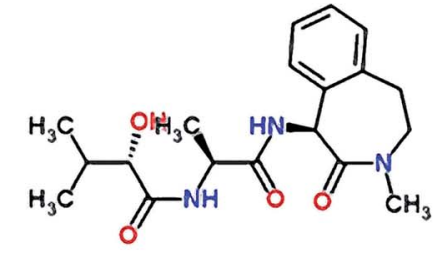

Semagacestat (LY-450139)

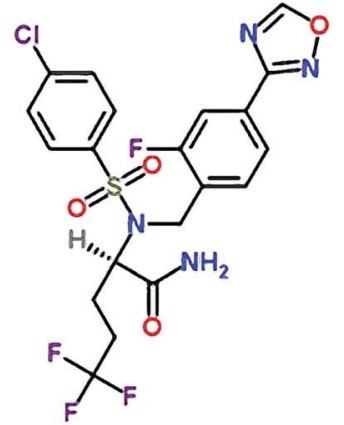

Avagacestat (BMS-708163)<smiles>O=S(=O)(N[C@@H](CO)C(C(F)(F)F)C(F)(F)F)c1ccc(Cl)s1</smiles>

Begacestat (GSI-953)<smiles>COC1[C@H](O)[C@@H](O)C(O)[C@H](O)[C@H]1O</smiles>

NIC5-15<smiles>O=C(O)C1(c2ccc(-c3ccc(Cl)c(Cl)c3)c(F)c2)CC1</smiles>

CHF 5074<smiles>COc1cc(/C=C2\CCCN(C(=O)C(C)(C)c3ccc(F)cc3)C2=O)ccc1-n1cnc(C)c1</smiles>

E2012

Fig. $4 \quad \gamma$-Secretase inhibitors and modulators in clinical trials.

preclinical studies. ${ }^{\mathbf{1 0 6}}$ Tau immunotherapy AADvac1 and ACI-35 are also under preclinical. ${ }^{107}$

4.2.2. Passive AD immunotherapy. AAB-001 (Bapineuzu$\mathrm{mab}$ ) is the first humanized monoclonal antibody targeting the $\mathrm{A} \beta \mathrm{N}$-terminus (A $\beta 1-5)$. The antibody binds strongly to deposite amyloid plaques to reduce the $\mathrm{A} \beta$ plaque burden and induces $\mathrm{Fc}$ mediated microglial phagocytosis of $A \beta$ plaques in mouse. ${ }^{108}$ Two phase 3 trials involved patients with mild-to-moderate Alzheimer disease were conducted, however, bapineuzumab failed to improve primary clinical outcomes. ${ }^{109}$ LY-2062430 (Solanezumab) is a humanized monoclonal antibody to the middomain of $A \beta 16-24$, which binds to the soluble $A \beta .{ }^{110}$ The compound has been proved safety in Phase 2 findings, nevertheless, neither clinical trial in phase 3, showing significant cognition improvement nor functional ability in patients with mild-to- moderate AD. ${ }^{111}$ Two previously phase 3 clinical trial results were renewed in some mild patients, and the secondary outcomes suggested that Solanezumab can slow the cognitive decline of 34\% according to the ADAS-Cog and Mini-Mental State Examination (MMSE) $(P<0.05) .{ }^{112}$ PF-04360365 (Ponezumab) is a humanized IgG2 $\delta$ A monoclonal antibody aiming to reduce immune effector. PF-04360365 showed accepted safety and well tolerated findings without antibody-induced side effects. ${ }^{113}$ And another clinical trial also showed similar results. ${ }^{\mathbf{1 1 4}}$ GSK-933776 is a humanized Fc-attenuated/inactivated anti-A $\beta$ monoclonal antibody. GSK933776 showed pharmacological activity and engaged target in plasma and CSF without causing brain amyloid-related imaging abnormalities-edema (ARIA-E/H) in patients with mild AD or MCI. ${ }^{115,116}$ MABT5102A was a humanized A $\beta 1-15$ monoclonal antibody with IgG4 isotype. It can inhibit $A \beta$ aggregation and promote its disaggregation without vasogenic edema and cerebral microhemorrhage induced by overactivation of microglial cells. ${ }^{117}$ Aducanumab (BIIB037) is a human monoclonal antibody that selectively targets misfolded $\mathrm{A} \beta$ peptides. Aducanumab restores calcium homeostasis in Tg2576 mice, ${ }^{\mathbf{1 1 8}}$ and also reduce soluble and insoluble $\mathrm{A} \beta$ in a dose-dependent manner. ${ }^{119}$ In a recent study, Sevigny et al. reports beneficial effects on the amyloid pathology and the cognitive status in patients with prodromal or mild AD. ${ }^{120}$ The phase $1 \mathrm{~b}$ clinical test had revitalizes the "amyloid cascade hypothesis" and bring mononuclear phagocytes to the center stage of $\mathrm{AD}$ treatment.

\subsection{Preventing $\mathbf{A} \boldsymbol{\beta}$ aggregation}

Tramiprosate (3-amino-1-propanesulfonic acid, 3APS) is an orally-administered amyloid antagonist, which binds to soluble $\mathrm{A} \beta$ peptide and designs to reduce $A \beta$ aggregation and prevent fibril formation. ${ }^{\mathbf{1 2 1}}$ Tramiprosate produces cytoprotective effects against $A \beta$-induced neurotoxicity, and exerts significant reduction of soluble and insoluble $A \beta$ in the brain of transgenic mice. ${ }^{122}$ Clinical trials show that tramiprosate can slow 
hippocampal atrophy, ${ }^{\mathbf{1 2 3}}$ and have some benefit on cognition. ${ }^{\mathbf{1 2 4}}$ However, the further Phase III trial has been terminated due to its unsuccessful in demonstrating efficacy. ${ }^{\mathbf{1 2 5 , 1 2 6}}$ Scyllo-inositol, an endogenous inositol stereoisomer, is another antiaggregation compound, exerting specific health-promoting effects for Alzheimer disease. ${ }^{127}$ It stabilized a small conformer of $\mathrm{A} \beta 42$ in vitro, and neutralized cell-derived $\mathrm{A} \beta$ oligomers in vivo. Moreover, scyllo-inositol can decrease neuronal toxicity and abate cognitive deficits in multiple mouse models of AD. ${ }^{128}$ A Phase II clinical trial demonstrated acceptable safety, however, primary clinical efficacy outcomes were not significant. ${ }^{129}$ Epigallo-catechin-3-gallate (EGCG), a natural flavanol derived from green tea which shows multiple neuroprotetive activities, ${ }^{\mathbf{1 3 0}}$ bind to unfolded peptide to prevent the formation of $\mathrm{A} \beta$ toxic oligomers. ${ }^{\mathbf{1 3 1}}$ It can also modulate cell signalling and reverse superoxide dismutase activity and the damage effects of $\mathrm{AlCl} 3$ neurotoxicity, which improves mitochondrial and cholinergic synaptic functions. ${ }^{132,133}$ PBT1 is a metal chelator that promotes the solubilisation by disturbing the chelation between $\mathrm{A} \beta$ and metal ions in vitro or mouse model studies. However, Phase II clinical suggested that there was no significant positive clinical benefit for patients with AD. Unfortunately, phase III trial was abandoned..$^{\mathbf{1 3 4}}$

The second-generation metal-protein attenuating compound PBT2, was developed as a metal chaperone which affected the metal-induced $\mathrm{A} \beta$ oligomerisation. ${ }^{\mathbf{1 3 5}}$ It has greater blood-brain barrier permeability. PBT2 can obstruct $\mathrm{A} \beta$ oligomerization, decrease soluble and insoluble $A \beta$ and promote the clearance of A $\beta$ oligomer. ${ }^{136}$ Phase II study showed that PBT2 can reduce the concentrations of $\mathrm{A} \beta 42$ in CSF and improved cognitive function with safety and tolerance. ${ }^{137}$ TTP488 (PF-04494700) is a smallmolecule oral antagonist of the receptor for advanced glycation end products. The low dose (5 $\mathrm{mg})$ shows good safety profile but associated with conclusive results in Phase II trial with mild to moderate AD. ${ }^{138}$ Another clinical trial demonstrates that low-dose ( $5 \mathrm{mg}$ ) could be a benefit dose in further Phase 3 trials in patients with mild $\mathrm{AD} .{ }^{139}$

A recent study provided a new framework for the rational identification of a series of drug candidates for neurodegenerative diseases, chemical kinetics approach was applied to study the effect of small molecules on the deposition rate of $\mathrm{A} \beta 42$ which was quantitatively analyzed. An anticancer drug, bexarotene, was reported to suppress $\mathrm{A} \beta 42$ deposition by targeting the primary nucleation step in the aggregation of $A \beta 42$ and delaying the formation of toxic species in neuroblastoma cells. ${ }^{140}$ Fig. 5 and Table $\mathrm{S} 5 \dagger$ show drugs in clinical trials to prevent $A \beta$ aggregation.

\section{Other potential therapeutic strategies in AD}

\subsection{Drugs to target Tau protein}

Leuco-methylthioninium (LMTX), a selective Tau aggregation inhibitor by preventing the formation and spread of NFTs and reducing the Tau pathology in transgenic mouse models, is the reduced form of methylthioninium (MT), which is the first substance that can degrade Tau protein. ${ }^{\mathbf{1 4 1}}$ An exploratory phase 2 study in mild or moderate Alzheimer's disease was conducted, safety and effectiveness was determined as well. ${ }^{\mathbf{1 4 2}}$ The main results of a broad participation of 115 academic centres in 15 months of randomised, controlled double-blind, parallel-group clinical trial is negative, the results do not suggest the benefit of LMTX as an additional treatment of mild to moderate Alzheimer's disease. ${ }^{\mathbf{1 4 3}}$<smiles>NCCCS(=O)(=O)O</smiles>

Tramiprosate<smiles>O[C@H]1[C@H](O)[C@H](O)[C@H](O)[C@@H](O)[C@H]1O</smiles>

Scyllo-inositol<smiles>Oc1c(I)cc(Cl)c2cccnc12</smiles>

Clioquinol<smiles>C=C(c1ccc(C(=O)O)cc1)c1cc2c(cc1C)C(C)(C)CCC2(C)C</smiles>

Bexarotene<smiles>O=C(OC1Cc2c(O)cc(O)cc2O[C@@H]1c1cc(O)c(O)c(O)c1)c1cc(O)c(O)c(O)c1</smiles>

Epigallocatechin-3-gallate

Fig. 5 Drugs in clinical trials to prevent $A \beta$ aggregation. 
Glycogen synthase kinase $3 \beta$ (GSK3 $\beta$ ) is a serine/threonine kinase which plays an important role in regulating Tau protein phosphorylation and involves in processing of amyloidbeta peptides. ${ }^{\mathbf{1 4 4 , 1 4 5}}$ Tideglusib (NP-031112) is a small non-ATP competitive GSK-3 inhibitor, for the treatment of Alzheimer's disease in clinical trials. It can lower Tau protein hyperphosphorylation, reduce brain amyloid plaque levels, improve learning and memory and prevent the loss of neurons in some animal models. ${ }^{\mathbf{1 4 6}}$ Studies demonstrated valuable safety in clinical trials in AD patients. ${ }^{147,148}$

\subsection{Neurotrophins}

Neurotrophins are dimeric peptide hormones. Nerve growth factor (NGF), the first neurotrophin, regulates many aspects of neuronal development and function, plays an important role in the survival and differentiation of neurons. ${ }^{149}$ Recently, the study shows that BDNF exerts substantial protective effects on crucial neuronal circuitry involved in Alzheimer's disease, revealed the correlation between the decreased NGF and AD. ${ }^{\mathbf{1 5 0}}$ Thus, neurotrophins have been acted as an attractive target for treatment of AD. AAV2-NGF (CERE-110) is designed to deliver NGF by gene to cross the blood-brain barrier, which increases production of acetylcholine and enhances the function basal forebrain cholinergic neurons. ${ }^{151,152}$ A Phase I study has been completed and a multi-center, placebo-controlled Phase II clinical trial in the observation phase. ${ }^{153} \mathrm{~T}-817 \mathrm{MA}[1-\{3-[2-(1-$ benzothiophen-5-yl)ethoxy]propyl\}azetidin-3-olmaleate] has both neuroprotective and neurotrophic effects and also has the ability to improve the cognitive impairment in transgenic mice ${ }^{154}$ The Phase II trial has been completed for its evaluations on safety and tolerability. ${ }^{155}$

\subsection{Targeting mitochondrial dysfunction}

There is a growing body of evidence supporting that mitochondrial dysfunction has a significant influence on the process of AD. ${ }^{156}$ Mitochondrial dysfunction also has connection with oxidative stress and Tau pathology. ${ }^{157,158}$ Due to the correlation between mitochondrial alterations and $\mathrm{AD}$, strategies targeting decreases the related oxidative stress and removal of damaged mitochondria possess great promise in $\mathrm{AD}$ treatment. Latrepirdine (Dimebon ${ }^{\circledR}$ ), a small molecule compound, is used for the treatment of $\mathrm{AD}$. Dimebon can modify hippocampal $\mathrm{APP} / \mathrm{A} \beta$ pathology, ${ }^{159}$ and ameliorate mitochondrial membrane potential and ATP production, ${ }^{\mathbf{1 6 0}}$ indicated the potential treatment for neurodegenerative diseases. ${ }^{161}$

\subsection{PPAR $\gamma$ agonists}

Pioglitazone is an insulin sensitizer of the thiazolidinedione class of peroxisome-proliferator activated receptor $\gamma$ (PPAR- $\gamma$ ) agonists. Takeda developed pioglitazone as a once-daily treatment of type 2 diabetes. The PPAR- $\gamma$ agonist improves cognition in $\mathrm{AD}$ mice, and mixed results in prior human trials. ${ }^{162}$ In August 2013, Takeda and Zinfandel Pharmaceuticals began 'Tomorrow', a Phase III trial that is to enroll 5800 cognitivelynormal participants and run for 4 years. The study has two separate goals; one is to evaluate how accurately a diagnostic algorithm based on the genes ApoE and TOMM40, developed by Zinfandel, predicts a person's risk of developing mild cognitive impairment due to $\mathrm{AD}$ within 5 years. The other is to evaluate pioglitazone's ability to delay this diagnosis.

\subsection{Computer simulation}

Studies showed that molecular dynamics simulation can be used to design $\mathrm{A} \beta$ aggregation inhibitor and a structure-based drug discovery procedure has been explored to identify the binding pockets between small-molecule and $A \beta$ peptide. ${ }^{163,164}$ In a study, a total 11 compounds were identified which reduce $\mathrm{A} \beta$ cytotoxicity by shifting the equilibrium of $\mathrm{A} \beta$ from oligomers to fibers by comprehensive performing these methods. ${ }^{\mathbf{1 6 5}} \mathrm{NQ}$ Trp (1,4-naphthoquinon-2-yl-L-tryptophan), a small molecular which has been reported to inhibit aggregation of $A \beta .{ }^{166} \mathrm{NQ}$-trp was found to be the best binders of five small-molecule drugs with $\mathrm{A} \beta 17-42$ by using a hierarchical computational procedure, ${ }^{167}$ further more, an extensive atomistic replica exchange molecular dynamics simulations was used to explain the beneficial effect of NQTrp in reducing both the level of A $\beta 1-42$ aggregation and toxicity. ${ }^{168}$ Aiming to investigate the molecular mechanism of NQ-Trp combined experimental and simulation studies were performed. The converging results explained its low inhibitory efficiency which due to the lack of specific "binding site"-type between NQ-Trp and A $\beta$, and suggested that another mechanism was involved in anti-AD activity of NQ-Trptype molecules models in vivo. ${ }^{169,170}$ Yang Z. et al. found that graphite can inhibit $A \beta$ peptide monomer fibrils and can clear the mature amyloid fibers through penetration and extraction of peptides. Experimental evidence such as molecular dynamics<smiles>O=c1sn(-c2cccc3ccccc23)c(=O)n1Cc1ccccc1</smiles>

Tideglusib(NP-031112)

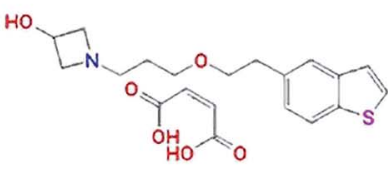

T-817MA

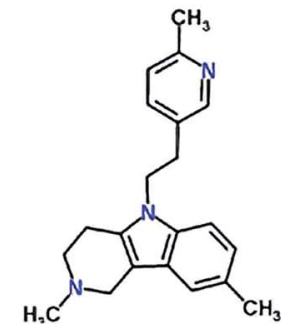

Latrepirdine
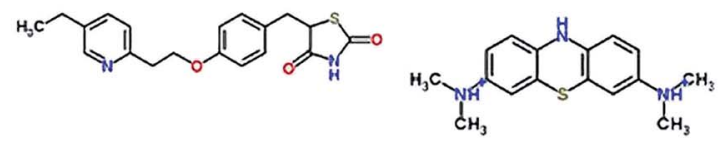

Fig. 6 Other potential therapeutic strategies in $A D$. 
simulations, atomic force microscopy images, thioflavin fluorescence assays, and cell viability and ROS assays confirmed the prediction results of computer simulation. ${ }^{171}$ The molecular mechanism and molecular dynamics of (-)-epigallocatechin gallate (EGCG) ${ }^{\mathbf{1 7 2}}$ and CQ1-3 (ref. 173) inhibiting A $\beta$ aggregation were studied respectively by computer simulation. Computer simulation provides new insights into the underlying molecular mechanisms that define drug-amyloid interaction and suggests the directions of further $\mathrm{AD}$ drug development. ${ }^{174}$ Fig. 6 and Table S6† show other potential therapeutic strategies in AD.

\section{Concluding remarks and future perspective}

So far, the development of AD drugs has achieved some success in the improvement of symptoms, whereas it also has several failed aspects of disease modification. While many clinical and drug design studies are undergoing, we must recognize that it is quite difficult to successfully cure $\mathrm{AD}$ with single therapy, which is attributed to the complex pathophysiology of $\mathrm{AD}$. It is believed not to be caused by single gene defects, but rather by a large number of genes, proteins and their complex interactions that ultimately lead to the change of this disease. ${ }^{175}$ Multitarget drug discovery may be a more promising treatment strategy for $\mathrm{AD} .{ }^{176}$ It could overcome the deficiency of the poor development effects of one-target-one-compound. Several multi target compounds already have been designed, such as dual binding AChE and BACE1 inhibitors, ${ }^{177}$ AChE inhibitors and antioxidants, ${ }^{178}$ which provide better therapeutic effects on both symptomatic and disease modifying in $\mathrm{AD}$. At this point, multiple-pharmacology natural products can be used as prototypes for the drugs design of AD treatment. ${ }^{179}$ Herbal formulae such as Kai-Xin-San (consisting of Ginseng Radix, Poria, Polygalae Radix, and Acori Tatarinowii Rhizoma) has been used in the treatment of Parkinson's disease and Alzheimer's disease, ${ }^{\mathbf{1 8 0 , 1 8 1}}$ also provide new insight for the treatment of AD. New methods, such as quantitative systems pharmacology, ${ }^{\mathbf{1 8 2}}$ chemogenomics knowledgebase, ${ }^{\mathbf{1 8 3}}$ metabolomics ${ }^{\mathbf{1 8 4 - 1 8 9}}$ and chinmedomics strategy ${ }^{\mathbf{1 9 0 - 1 9 5}}$ will meet the challenge and provide a promising avenue for the discovery and clinical development of newgeneration drugs for $\mathrm{AD}$.

\section{Competing financial interests}

The authors declare no competing financial interests.

\section{Acknowledgements}

This work was supported by grants from the Key Program of Natural Science Foundation of State (Grant No. 81302905, 81373930, 81430093, 81673586), National Key Subject of Drug Innovation (Grant No. 2015ZX09101043-005, 2015ZX09101043011), TCM State Administration Subject of Public Welfare of (Grant No. 2015468004), Natural Science Foundation of Heilongjiang Province of China (H2015038), University Nursing
Program for Young Scholars with Creative Talents in Heilongjiang Province (UNPYSCT-2015118).

\section{References}

1 H. W. Querfurth and F. M. Laferla, N. Engl. J. Med., 2010, 362(4), 329-344.

2 A. Wimo, B. Winblad and L. Jonsson, Alzheimer's \& Dementia, 2010, 6(2), 98-103.

3 M. P. Mattson, Nature, 2004, 430(7000), 631-639.

4 K. G. Mawuenyega, Science, 2010, 330, 1774.

5 D. P. Hanger, B. H. Anderton and W. Noble, Trends Mol. Med., 2009, 15(3), 112-119.

6 B. Su, X. Wang, A. Nunomura, P. I. Moreira, H. G. Lee, G. Perry, M. A. Smith and X. Zhu, Curr. Alzheimer Res., 2008, 5(6), 525-532.

7 L. A. Craig, N. S. Hong and R. J. McDonald, Neurosci. Biobehav. Rev., 2011, 35(6), 1397-1409.

8 C. Holmes, Neuropathol. Appl. Neurobiol., 2013, 39(1), 51-68. 9 M. A. Greenough, J. Camakaris and A. I. Bush, Neurochem. Int., 2013, 62(5), 540-555.

10 J. Hardy, Curr. Alzheimer Res., 2006, 3, 71-73.

11 C. Haass and D. J. Selkoe, Nat. Rev. Mol. Cell Biol., 2007, 8, 101-112.

12 C. Nerelius, M. Fitzen and J. Johansson, Biochem. Biophys. Res. Commun., 2010, 396, 2-6.

13 R. E. Tanzi and L. Bertram, Cell, 2005, 120, 545-555.

14 D. M. Walsh and D. J. Selkoe, J. Neurochem., 2007, 101, 1172-1184.

15 R. Gallardo, M. Ramakers, F. De Smet, F. Claes, L. Khodaparast, J. R. Couceiro, T. Langenberg, M. Siemons, S. Nyström, L. J. Young, R. F. Laine, L. Young, E. Radaelli, I. Benilova, M. Kumar, A. Staes, M. Desager, M. Beerens, P. Vandervoort, A. Luttun, K. Gevaert, G. Bormans, M. Dewerchin, J. Van Eldere, P. Carmeliet, G. Vande Velde, C. Verfaillie, C. F. Kaminski, B. De Strooper, P. Hammarström, K. P. Nilsson, L. Serpell, J. Schymkowitz and F. Rousseau, Science, 2016, 354(6313), aah4949.

16 D. J. Selkoe and J. Hardy, EMBO Mol. Med., 2016, 8(6), 595608.

17 S. Konzack, E. Thies, A. Marx, E. M. Mandelkow and E. Mandelkow, J. Neurosci., 2007, 27, 9916-9927.

18 L. Buée, T. Bussière, V. Buée-Scherrer, A. Delacourte and P. R. Hof, Brain Res. Rev., 2000, 33, 95-130.

19 J. P. Brion, C. Smith, A. M. Couck, J. M. Gallo and B. H. Anderton, J. Neurochem., 1993, 61, 2071-2080.

20 D. P. Hanger, B. H. Anderton and W. Noble, Trends Mol. Med., 2009, 15(3), 112-119.

21 E. D. Roberson, Science, 2007, 316, 750-754.

22 M. Jin, N. Shepardson, T. Yang, G. Chen, D. Walsh and D. J. Selkoe, Proc. Natl. Acad. Sci. U. S. A., 2011, 108(14), 5819-5824.

23 M. Valko, D. Leibfritz, J. Moncol, M. T. Cronin, M. Mazur and J. Telser, Int. J. Biochem. Cell Biol., 2007, 39(1), 44-84.

24 M. Mohsenzadegan and A. Mirshafiey, Iran. J. Allergy, Asthma Immunol., 2012, 11(3), 203-216. 
25 A. Nunomura, R. J. Castellani, X. Zhu, P. I. Moreira, G. Perry and M. A. Smith, J. Neuropathol. Exp. Neurol., 2006, 65, 631641.

26 C. Pocernich and D. Butterfield, Biochim. Biophys. Acta, 2012, 1822(5), 625-630.

27 R. T. Bartus, R. L. Dean 3rd, B. Beer and A. S. Lippa, Science, 1982, 217(4558), 408-414.

28 R. Schliebs and T. Arendt, Behav. Brain Res., 2011, 221, 555563.

29 D. S. Auld, T. J. Kornecook, S. Bastianetto and R. Quirion, Prog. Neurobiol., 2003, 3, 209-245.

30 R. Schliebs and T. Arendt, J. Neural Transm., 2006, 113, 1625-1644.

31 J. Berger-Sweeney, Neurosci. Biobehav. Rev., 2003, 27, 401411.

32 H. Akiyama, S. Barger, S. Barnum, B. Bradt, J. Bauer, G. M. Cole, N. R. Cooper, P. Eikelenboom, M. Emmerling, B. L. Fiebich, C. E. Finch, S. Frautschy, W. S. Griffin, H. Hampel, M. Hull, G. Landreth, L. Lue, R. Mrak, I. R. Mackenzie, P. L. McGeer, M. K. O'Banion, J. Pachter, G. Pasinetti, C. Plata-Salaman, J. Rogers, R. Rydel, Y. Shen, W. Streit, R. Strohmeyer, I. Tooyoma, F. L. Van Muiswinkel, R. Veerhuis, D. Walker, S. Webster, B. Wegrzyniak, G. Wenk and T. Wyss-Coray, Neurobiol. Aging, 2000, 21, 383-421.

33 W. S. Griffin and R. E. Mrak, J. Leukocyte Biol., 2002, 72(2), 233-238.

34 C. E. Finch and T. E. Morgan, Curr. Alzheimer Res., 2007, 4, 185-189.

35 T. Town, V. Nikolic and J. Tan, J. Neuroinflammation, 2005, $2,24$.

36 E. E. Tuppo and H. R. Arias, Cell Biol., 2005, 37, 289-305.

37 G. Halliday, S. R. Robinson, C. Shepherd and J. Kril, Clin. Exp. Pharmacol. Physiol., 2000, 27, 1-8.

38 M. Farina, D. S. Avila, J. B. da Rocha and M. Aschner, Neurochem. Int., 2013, 62(5), 575-594.

39 S. Bolognin, L. Messori and P. Zatta, NeuroMol. Med., 2009, 11(4), 223-238.

40 M. G. Savelieff, S. Lee, Y. Liu and M. H. Lim, ACS Chem. Biol., 2013, 8(5), 856-865.

41 B. F. Popescu and H. Nichol, CNS Neurosci. Ther., 2011, 17, 256-268.

42 W. Zheng and A. D. Monnot, Pharmacol. Ther., 2012, 133(2), 177-188.

43 K. Jomova, D. Vondrakova, M. Lawson and M. Valko, Mol. Cell. Biochem., 2010, 345(1-2), 91-104.

44 B. B. Muhoberac and R. Vidal, Front. Aging Neurosci., 2013, $5,32$.

45 M. Kawahara, J. Alzheimer's Dis., 2005, 8(2), 171-182, discussion 209-115.

46 J. R. Walton, J. Alzheimer's Dis., 2013, 35(1), 7-43.

47 A. Campbell, J. Alzheimer's Dis., 2006, 10(2-3), 165-172.

48 E. House, M. Esiri, G. Forster, P. G. Ince and C. Exley, Metallomics, 2012, 4(1), 56-65.

49 D. A. Drachman and J. Leavitt, Arch. Neurol., 1974, 30, 113121.

50 T. Babic, J. Neurol., Neurosurg. Psychiatry, 1999, 67(4), 558.
51 R. Schliebs and T. Arendt, J. Neural Transm., 2006, 113, 1625-1644.

52 D. S. Auld, T. J. Kornecook, S. Bastianetto and R. Quirion, Prog. Neurobiol., 2003, 3, 209-245.

53 A. S. Relman, N. Engl. J. Med., 1991, 324, 349-352, DOI: 10.1056/nejm199101313240525.

54 M. J. Knapp, D. S. Knopman, P. R. Solomon, W. W. Pendlebury, C. S. Davis and S. I. Gracon, J. Am. Med. Assoc., 1994, 271, 985-991.

55 J. S. Birks, D. Melzer and H. Beppu, Cochrane Database of Systematic Reviews, 2000, 4, CD001190.

56 J. Birks and R. J. Harvey, Cochrane Database of Systematic Reviews, 2006, 25(1), CD001190.

57 J. Birks, J. Grimley Evans, V. Iakovidou and M. Tsolaki, Cochrane Database of Systematic Reviews, 2009, CD001191.

58 C. Loy and L. Schneider, Cochrane Database of Systematic Reviews, 2006, 1, CD001747.

59 R. E. Becker, N. H. Greig and E. Giacobini, J. Alzheimer's Dis., 2008, 15, 303-325.

60 R. A. McArthur, J. Gray and R. Schreiber, Curr. Opin. Invest. Drugs, 2010, 11, 740-760.

61 B. Reisberg, R. Doody, A. Stöffler, F. Schmitt, S. Ferris, H. J. Möbius and Memantine Study Group, N. Engl. J. Med., 2003, 348(14), 1333-1341.

62 D. Olivares, V. K. Deshpande, Y. Shi, D. K. Lahiri, N. H. Greig, J. T. Rogers and X. Huang, Curr. Alzheimer Res., 2012, 9(6), 746-758.

63 L. M. Fu and J. T. Li, J. Evidence-Based Complementary Altern. Med., 2011, 2011, 640284.

64 S. H. Xing, C. X. Zhu, R. Zhang and L. An, J. Evidence-Based Complementary Altern. Med., 2014, 2014, 363985.

65 G. Yang, Y. Wang, J. Tian and J. P. Liu, PLoS One, 2013, 8(9), e74916.

66 M. S. Rafii, S. Walsh, J. T. Little, K. Behan, B. Reynolds, C. Ward, S. Jin, R. Thomas and P. S. Aisen, Neurology, 2011, 76(16), 1389-1394.

67 J. Yue, B. R. Dong, X. Lin, M. Yang, H. M. Wu and T. Wu, Cochrane Database of Systematic Reviews, 2012, 12, CD008827.

68 J. Y. Jia, Q. H. Zhao, Y. Liu, Y. Z. Gui, G. Y. Liu, D. Y. Zhu, C. Yu and Z. Hong, Acta Pharmacol. Sin., 2013, 34(7), 976-982.

69 F. Coelho and J. Birks, Cochrane Database of Systematic Reviews, 2001, 2, CD001499.

70 B. Winblad, E. Giacobini, L. Frolich, L. T. Friedhoff, G. Bruinsma, R. E. Becker and N. H. Greig, J. Alzheimer's Dis., 2010, 22(4), 1201-1208.

71 S. Bhattacharya, A. Maelicke and D. Montag, J. Alzheimer's Dis., 2015, 46(1), 123-136.

72 A. Maelicke, A. Hoeffle-Maas, J. Ludwig, A. Maus, M. Samochocki, U. Jordis and A. K. Koepke, J. Mol. Neurosci., 2010, 40(1-2), 135-137.

73 O. Weinreb, T. Amit, O. Bar-Am and M. B. Youdim, Curr. Drug Targets, 2012, 13(4), 483-494.

74 A. Fisher, Neurodegener. Dis., 2008, 5(3-4), 237-240.

75 A. Fisher, R. Brandeis, R. H. Bar-Ner, M. Kliger-Spatz, N. Natan, H. Sonego, I. Marcovitch and Z. Pittel, J. Mol. Neurosci., 2002, 19(1-2), 145-153. 
76 J. Prickaerts, N. P. van Goethem, R. Chesworth, G. Shapiro, F. G. Boess, C. Methfessel, O. A. Reneerkens, D. G. Flood, D. Hilt, M. Gawryl, S. Bertrand, D. Bertrand and G. König, Neuropharmacology, 2012, 62(2), 1099-1110.

77 P. Zawieja, J. M. Kornprobst and P. Metais, Geriatrics \& Gerontology International, 2012, 12(3), 365-371.

78 P. C. May, R. A. Dean, S. L. Lowe, F. Martenyi, S. M. Sheehan, L. N. Boggs, S. A. Monk, B. M. Mathes, D. J. Mergott, B. M. Watson, S. L. Stout, D. E. Timm, E. Smith Labell, C. R. Gonzales, M. Nakano, S. Jhee, S. M. Yen, Y. L. Ereshefsk, T. D. Lindstrom, D. O. Calligaro, P. J. Cocke, D. Greg Hall, S. Friedrich, M. Citron and J. E. Audia, J. Neurosci., 2011, 31(46), 16507-16516.

79 F. Martenyi, R. A. Dean, S. Lowe, M. Nakano, S. Monk, B. A. Willis, C. Gonzales, D. Mergott, D. Leslie, P. May, A. James, H. Gevorkyan, S. Jhee, L. Ereshefsky and M. Citron, Alzheimer's \& Dementia, 2012, 8(4), P583-P584.

80 B. Willis, F. Martenyi, R. Dean, S. Lowe, M. Nakano, S. Monk, C. Gonzales, D. Mergott, L. Daugherty, M. Citron and P. May, Alzheimer's \& Dementia, 2012, 8, P582.

81 M. Forman, J. Palcza, J. Tseng, J. Leempoels, S. Ramael, D. Han, S. Jhee, L. Ereshefsky, M. Tanen, O. Laterza, M. Dockendorf, G. Krishna, L. Ma, J. Wagner and M. Troyer, Alzheimer's \& Dementia, 2012, 8(4), 704-705.

82 M. Forman, H. J. Kleijn, M. Dockendorf, J. Palcza, J. Tseng, C. Canales, M. Egan, M. Kennedy, O. Laterza, L. Ma, J. Scott, M. Tanen, J. Apter, M. Backonja, L. Ereshefsky, H. Gevorkyan, S. Jhee, R. Rynders, A. Zari, E. Bryan, J. Wagner, M. Troyer and J. Stone, Alzheimer's \& Dementia, 2013, 9, 139.

83 M. E. Kennedy, A. W. Stamford, X. Chen, K. Cox, J. N. Cumming, M. F. Dockendorf, M. Egan, L. Ereshefsky, R. A. Hodgson, L. A. Hyde, S. Jhee, H. J. Kleijn, R. Kuvelkar, W. Li, B. A. Mattson, H. Mei, J. Palcza, J. D. Scott, M. Tanen, M. D. Troyer, J. L. Tseng, J. A. Stone, E. M. Parker and M. S. Forman, Sci. Transl. Med., 2016, 8(363), 363ra150.

84 R. Lai, B. Albala, J. M. Kaplow, J. Aluri, M. Yen and A. Satlin, Alzheimer's \& Dementia, 2012, 8, 96.

85 F. Bernier, Y. Sato, M. Matijevic, H. Desmond, S. M. Grath, L. Burns, J. M. Kaplow and B. Albala, Alzheimer's \& Dementia, 2013, 9, 886.

86 D. B. Henley, P. C. May, R. A. Dean and E. R. Siemers, Expert Opin. Pharmacother., 2009, 10(10), 1657-1664.

87 K. Blennow, H. Zetterberg, C. Haass and T. Finucane, Nat. Med., 2013, 19(10), 1214-1215.

88 R. S. Doody, R. Raman, M. Farlow, T. Iwatsubo, B. Vellas, S. Joffe, K. Kieburtz, F. He, X. Sun, R. G. Thomas, P. S. Aisen, E. Siemers, G. Sethuraman and R. Mohs, N. Engl. J. Med., 2013, 369(4), 341-350.

89 V. Coric, S. Salloway, C. H. van Dyck, B. Dubois, N. Andreasen, M. Brody, C. Curtis, H. Soininen, S. Thein, T. Shiovitz, G. Pilcher, K. Ferrarek, J. Seibyl, J. M. Cedarbaum, C. Albright, H. H. Feldman and R. M. Berman, JAMA Neurology, 2015, 72(11), 1324-1333.
90 R. L. Martone, H. Zhou, K. Atchison, T. Comery, J. Z. Xu, X. Huang, X. Gong, M. Jin, A. Kreft, B. Harrison, S. C. Mayer, S. Aschmies, C. Gonzales, M. M. Zaleska, D. R. Riddell, E. Wagner, P. Lu, S. C. Sun, J. SonnenbergReines, A. Oganesian, K. Adkins, M. W. Leach, D. W. Clarke, D. Huryn, M. Abou-Gharbia, R. Magolda, J. Bard, G. Frick, S. Raje, S. B. Forlow, C. Balliet, M. E. Burczynski, P. H. Reinhart, H. I. Wan, M. N. Pangalos and J. S. Jacobsen, J. Pharmacol. Exp. Ther., 2009, 331(2), 598-608.

91 C. R. Hopkins, ACS Chem. Neurosci., 2012, 3(1), 3-4.

92 G. Pasinetti, Z. Rosen and H. Grossman, Alzheimer's \& Dementia, 2009, 5(4), e28.

93 H. Grossman, G. Marzloff, X. Luo, D. Leroith, M. Sano and G. Pasinetti, Alzheimer's \& Dementia, 2009, 5(4), P259.

94 B. P. Imbimbo, B. Hutter-Paier, G. Villetti, F. Facchinetti, V. Cenacchi, R. Volta, A. Lanzillotta, M. Pizzi and M. Windisch, Br. J. Pharmacol., 2009, 156(6), 982-993.

95 J. Ross, S. Sharma, J. Winston, M. Nunez, G. Bottini, M. Franceschi, E. Scarpini, E. Frigerio, F. Fiorentini, M. Fernandez, S. Sivilia, L. Giardino, L. Calza, D. Norris, H. Cicirello, D. Casula and B. P. Imbimbo, Curr. Alzheimer Res., 2013, 10(7), 742-753.

96 T. Hashimoto, A. Ishibashi, H. Hagiwara, Y. Murata, O. Takenaka and T. Miyagawa, Alzheimer's \& Dementia, 2010, 6(4), S242.

97 C. Holmes, D. Boche, D. Wilkinson, G. Yadegarfar, V. Hopkins, A. Bayer, R. W. Jones, R. Bullock, S. Love, J. W. Neal, E. Zotova and J. A. Nicoll, Lancet, 2008, 372, 216-223.

98 B. Winblad, N. Andreasen, L. Minthon, A. Floesser, G. Imbert, T. Dumortier, R. P. Maguire, K. Blennow, J. Lundmark, M. Staufenbiel, J. M. Orgogozo and A. Graf, Lancet Neurol., 2012, 11(7), 597-604.

99 A. Muhs, D. T. Hickman, M. Pihlgren, N. Chuard, V. Giriens, C. Meerschman, I. van der Auwera, F. van Leuven, M. Sugawara, M. C. Weingertner, B. Bechinger, R. Greferath, N. Kolonko, L. Nagel-Steger, D. Riesner, R. O. Brady, A. Pfeifer and C. Nicolau, Proc. Natl. Acad. Sci. U. S. A., 2007, 104(23), 9810-9815.

100 C. Y. Wang, C. L. Finstad, A. M. Walfield, C. Sia, K. K. Sokoll, T. Y. Chang, X. D. Fang, C. H. Hung, B. Hutter-Paier and M. Windisch, Vaccine, 2007, 25, 30413052 .

101 D. Galimberti, L. Ghezzi and E. Scarpini, J. Neurol. Sci., 2013, 333(1-2), 50-54.

102 H. Arai, H. Suzuki and T. Yoshiyama, Curr. Alzheimer Res., 2015, 12(3), 242-254.

103 J. M. Savage, G. Wu, A. McCampbell, R. K. Wessner, M. Citron, X. Liang, S. Hsieh, A. L. Wolfe, G. G. Kinney, B. L. Rosen and J. J. Renger, Alzheimer's \& Dementia, 2010, 6, S142.

104 H. Davtyan, A. Ghochikyan, I. Petrushina, A. Hovakimyan, A. Davtyan, A. Poghosyan, A. M. Marleau, N. Movsesyan, A. Kiyatkin, S. Rasool, A. K. Larsen, P. J. Madsen, K. M. Wegener, D. K. Ditlevsen, D. H. Cribbs, 
L. O. Pedersen and M. G. Agadjanyan, J. Neurosci., 2013, 33(11), 4923-4934.

105 S. Hendrix, N. Ellison, S. Stanworth, L. Tierney, F. Mattner, W. Schmidt, B. Dubois and A. Schneeberger, Journal of Prevention of Alzheimer's Disease, 2015, 2(2), 91-102.

106 D. Lambracht-Washington, B. X. Qu, M. Fu, L. D. Anderson Jr, O. Stuve, T. N. Eagar and R. N. Rosenberg, Cell. Mol. Neurobiol., 2011, 31, 867-874.

107 B. Winblad, A. Graf, M. E. Riviere, N. Andreasen and J. M. Ryan, Alzheimer's Res. Ther., 2014, 6(1), 7.

108 F. Bard, R. Barbour, C. Cannon, R. Carretto, M. Fox, D. Games, T. Guido, K. Hoenow, K. Hu, K. JohnsonWood, K. Khan, D. Kholodenko, C. Lee, M. Lee, R. Motter, M. Nguyen, A. Reed, D. Schenk, P. Tang, N. Vasquez, P. Seubert and T. Yednock, Proc. Natl. Acad. Sci. U. S. A., 2003, 100(4), 2023-2028.

109 S. Salloway, R. Sperling, N. C. Fox, K. Blennow, W. Klunk, M. Raskind, M. Sabbagh, L. S. Honig, A. P. Porsteinsson, S. Ferris, M. Reichert, N. Ketter, B. Nejadnik, V. Guenzler, M. Miloslavsky, D. Wang, Y. Lu, J. Lull, I. C. Tudor, E. Liu, M. Grundman, E. Yuen, R. Black, H. R. Brashear and Bapineuzumab 301 and 302 Clinical Trial Investigators, N. Engl. J. Med., 2014, 370, 322-333.

110 H. Samadi and D. Sultzer, Expert Opin. Biol. Ther., 2011, 11(6), 787-798.

111 R. S. Doody, R. G. Thomas, M. Farlow, T. Iwatsubo, B. Vellas, S. Joffe, K. Kieburtz, R. Raman, X. Sun, P. S. Aisen, E. Siemers, H. Liu-Seifert, R. Mohs, Alzheimer's Disease Cooperative Study Steering Committee and Solanezumab Study Group, N. Engl. J. Med., 2014, 370(4), 311-321.

112 E. R. Siemers, K. L. Sundell, C. Carlson, M. Case, G. Sethuraman, H. Liu-Seifert, S. A. Dowsett, M. J. Pontecorvo, R. A. Dean and R. Demattos, Alzheimer's \& Dementia, 2016, 12(2), 110-120.

113 G. B. Freeman, J. C. Lin, J. Pons and N. M. Raha, J. Alzheimer's Dis., 2012, 28(3), 531-541.

114 I. Miyoshi, Y. Fujimoto, M. Yamada, S. Abe, Q. Zhao, C. Cronenberger, K. Togo, T. Ishibashi, M. M. Bednar, J. W. Kupiec and B. Binneman, Int. J. Clin. Pharmacol. Ther., 2013, 51(12), 911-923.

115 T. Leyhe, N. Andreasen, M. Simeoni, A. Reich, C. A. von Arnim, X. Tong, A. Yeo, S. Khan, A. Loercher, M. Chalker, C. Hottenstein, H. Zetterberg, J. Hilpert and P. Mistry, Alzheimer's Res. Ther., 2014, 6(2), 19.

116 N. Andreasen, M. Simeoni, H. Ostlund, P. I. Lisjo, T. Fladby, A. E. Loercher, G. J. Byrne, F. Murray, P. T. Scott-Stevens, A. Wallin, Y. Y. Zhang, L. H. Bronge, H. Zetterberg, A. K. Nordberg, A. J. Yeo, S. A. Khan, J. Hilpert and P. C. Mistry, PLoS One, 2015, 10(3), e0098153.

117 O. Adolfsson, M. Pihlgren, N. Toni, Y. Varisco, A. L. Buccarello, K. Antoniello, S. Lohmann, K. Piorkowska, V. Gafner, J. K. Atwal, J. Maloney, M. Chen, A. Gogineni, R. M. Weimer, D. L. Mortensen, M. Friesenhahn, C. Ho, R. Paul, A. Pfeifer, A. Muhs and R. J. Watts, J. Neurosci., 2012, 32(28), 9677-9689.
118 K. V. Kastanenka, T. Bussiere, N. Shakerdge, F. Qian, P. H. Weinreb, K. Rhodes and B. J. Bacskai, J. Neurosci., 2016, pii, 2080-2116.

119 J. Ferrero, L. Williams, H. Stella, K. Leitermann, A. Mikulskis, J. O'Gorman and J. Sevigny, Alzheimer's \& Dementia, Translational Research \& Clinical Interventions, 2016, 2(3), 169-176.

120 J. Sevigny, P. Chiao, T. Bussière, P. H. Weinreb, L. Williams, M. Maier, R. Dunstan, S. Salloway, T. Chen, Y. Ling, J. O'Gorman, F. Qian, M. Arastu, M. Li, S. Chollate, M. S. Brennan, O. Quintero-Monzon, R. H. Scannevin, H. M. Arnold, T. Engber, K. Rhodes, J. Ferrero, Y. Hang, A. Mikulskis, J. Grimm, C. Hock, R. M. Nitsch and A. Sandrock, Nature, 2016, 537(7618), 50-56.

121 P. S. Aisen, S. Gauthier, B. Vellas, R. Briand, D. Saumier, J. Laurin and D. Garceau, Curr. Alzheimer Res., 2007, 4(4), 473-478.

122 F. Gervais, J. Paquette, C. Morissette, P. Krzywkowski, M. Yu, M. Azzi, D. Lacombe, X. Kong, A. Aman, J. Laurin, W. A. Szarek and P. Tremblay, Neurobiol. Aging, 2007, 28(4), 537-547.

123 S. Gauthier, P. S. Aisen, S. H. Ferris, D. Saumier, A. Duong, D. Haine, D. Garceau, J. Suhy, J. Oh, W. Lau and J. Sampalis, J. Nutr., Health Aging, 2009, 13(6), 550-557.

124 D. Saumier, A. Duong, D. Haine, D. Garceau and J. Sampalis, J. Nutr., Health Aging, 2009, 13(9), 808-812.

125 P. S. Aisen, S. Gauthier, S. H. Ferris, D. Saumier, D. Haine, D. Garceau, A. Duong, J. Suhy, J. Oh, W. C. Lau and J. Sampalis, Arch. Med. Sci., 2011, 7(1), 102-111.

126 N. Herrmann, S. A. Chau, I. Kircanski and K. L. Lanctôt, Drugs, 2011, 71(15), 2031-2065.

127 K. Tanaka, S. Takanaka and K. Yoshida, Bioengineered, 2014, 5(5), 331-334.

128 K. Ma, L. A. Thomason and J. Mclaurin, Adv. Pharmacol., 2012, 64, 177-212.

129 S. Salloway, R. Sperling, R. Keren, A. P. Porsteinsson, C. H. van Dyck, P. N. Tariot, S. Gilman, D. Arnold, S. Abushakra, C. Hernandez, G. Crans, E. Liang, G. Quinn, M. Bairu, A. Pastrak, J. M. Cedarbaum and ELND005-AD201 Investigators, Neurology, 2011, 77(13), 1253-1262.

130 L. Xicota, J. Rodríguez-Morató, M. Dierssen and R. de la Torre, Curr. Drug Targets, 2015, Epub ahead of print.

131 S. A. Mandel, T. Amit, L. Kalfon, L. Reznichenko, O. Weinreb and M. B. Youdim, J. Alzheimer's Dis., 2008, 15(2), 211-222.

132 T. Jayasena, A. Poljak, G. Smythe, N. Braidy, G. Münch and P. Sachdev, Ageing Res. Rev., 2013, 12(4), 867-883.

133 A. Jelenković, M. D. Jovanović, I. Stevanović, N. Petronijević, D. Bokonjić, J. Zivković and R. Igić, Phytother. Res., 2014, 28(1), 82-87.

134 E. L. Sampson, L. Jenagaratnam and R. McShane, Cochrane Database of Systematic Reviews, 2012, 5, CD005380.

135 P. A. Adlard, A. Sedjahtera, L. Gunawan, L. Bray, D. Hare, J. Lear, P. Doble, A. I. Bush, D. I. Finkelstein and R. A. Cherny, Aging Cell, 2013, 13(2), 351-359. 
136 P. A. Adlard, R. A. Cherny, D. I. Finkelstein, E. Gautier, E. Robb, M. Cortes, I. Volitakis, X. Liu, J. P. Smith, K. Perez, K. Laughton, Q. X. Li, S. A. Charman, J. A. Nicolazzo, S. Wilkins, K. Deleva, T. Lynch, G. Kok, C. W. Ritchie, R. E. Tanzi, R. Cappai, C. L. Masters, K. J. Barnham and A. I. Bush, Neuron, 2008, 59(1), 43-55.

137 L. Lannfelt, K. Blennow, H. Zetterberg, S. Batsman, D. Ames, J. Harrison, C. L. Masters, S. Targum, A. I. Bush, R. Murdoch, J. Wilson, C. W. Ritchie and PBT2-201-EURO study group, Lancet Neurol., 2008, 7(9), 779-786.

138 D. Galasko, J. Bell, J. Y. Mancuso, J. W. Kupiec, M. N. Sabbagh, C. van Dyck, R. G. Thomas and P. S. Aisen, Neurology, 2014, 82, 1536-1542.

139 A. H. Burstein, I. Grimes, D. R. Galasko, P. S. Aisen and M. Sabbagh, BMC Neurol., 2014, 14, 12.

140 J. Habchi, P. Arosio, M. Perni, A. R. Costa, M. Yagi-Utsumi, P. Joshi, S. Chia, S. I. Cohen, M. B. Müller, S. Linse, E. A. Nollen, C. M. Dobson, T. P. Knowles and M. Vendruscolo, Sci. Adv., 2016, 2(2), e1501244.

141 D. Seripa, V. Solfrizzi, B. P. Imbimbo, A. Daniele, A. Santamato, M. Lozupone, G. Zuliani, A. Greco, G. Logroscino and F. Panza, Expert Rev. Neurother., 2016, 16(3), 259-277.

142 C. M. Wischik, R. T. Staff, D. J. Wischik, P. Bentham, A. D. Murray, J. M. Storey, K. A. Kook and C. R. Harrington, J. Alzheimer's Dis., 2015, 44(2), 705-720.

143 S. Gauthier, H. H. Feldman, L. S. Schneider, G. K. Wilcock, G. B. Frisoni, J. H. Hardlund, H. J. Moebius, P. Bentham, K. A. Kook, D. J. Wischik, B. O. Schelter, C. S. Davis, R. T. Staff, L. Bracoud, K. Shamsi, J. M. Storey, C. R. Harrington and C. M. Wischik, Lancet, 2016, pii, S0140.

144 C. J. Phiel, C. A. Wilson, V. M. Lee and P. S. Klein, Nature, 2003, 423(6938), 435-439.

145 E. Rockenstein, M. Torrance, A. Adame, M. Mante, P. Baron, J. B. Rose, L. Crews and E. Masliah, J. Neurosci., 2007, 27(8), 1981-1991.

146 J. M. Domínguez, A. Fuertes, L. Orozco, M. del MonteMillán, E. Delgado and M. Medina, J. Biol. Chem., 2012, 287(2), 893-904.

147 T. del Ser, K. C. Steinwachs, H. J. Gertz, M. V. Andrés, B. Gómez-Carrillo, M. Medina, J. A. Vericat, P. Redondo, D. Fleet and T. León, J. Alzheimer's Dis., 2013, 33(1), 205215.

148 S. Lovestone, M. Boada, B. Dubois, M. Hüll, J. O. Rinne, H. J. Huppertz, M. Calero, M. V. Andrés, B. GómezCarrillo, T. León, T. del Ser and ARGO investigators, $J$. Alzheimer's Dis., 2015, 45(1), 75-88.

149 L. F. Reichardt, Philos. Trans. R. Soc. London, Ser. B, 2006, 361(1473), 1545-1564.

150 A. H. Nagahara, D. A. Merrill, G. Coppola, S. Tsukada, B. E. Schroeder, G. M. Shaked, L. Wang, A. Blesch, A. Kim, J. M. Conner, E. Rockenstein, M. V. Chao, E. H. Koo, D. Geschwind, E. Masliah, A. A. Chiba and M. H. Tuszynski, Nat. Med., 2009, 15(3), 331-337.

151 R. J. Mandel, Curr. Opin. Mol. Ther., 2010, 12(2), 240-247. 152 F. Hefti, J. Neurosci., 1986, 6, 2155-2162.
153 M. S. Rafii, T. L. Baumann, R. A. Bakay, J. M. Ostrove, J. Siffert, A. S. Fleisher, C. D. Herzog, D. Barba, M. Pay, D. P. Salmon, Y. Chu, J. H. Kordower, K. Bishop, D. Keator, S. Potkin and R. T. Bartus, Alzheimer's \& Dementia, 2014, 10, 571-581.

154 T. Fukushima, A. Nakamura, N. Iwakami, Y. Nakada, H. Hattori, S. Hoki, H. Yamaguchi, M. Nakagawa, N. Terashima and H. Narita, Biochem. Biophys. Res. Commun., 2011, 407(4), 730-734.

155 H. Liu, L. Wang, W. Su and X. Q. Xie, Pharm. Pat. Anal., 2014, 3(4), 429-447.

156 V. García-Escudero, P. Martín-Maestro, G. Perry and J. Avila, Oxid. Med. Cell. Longevity, 2013, 2013, 162152.

157 X. Wang, W. Wang, L. Li, G. Perry, H. G. Lee and X. Zhu, Biochim. Biophys. Acta, 2013, 1842(8), 1240-1247.

158 R. A. Quintanilla, T. A. Matthews-Roberson, P. J. Dolan and G. V. Johnson, J. Biol. Chem., 2009, 284(28), 1875418766.

159 S. E. Perez, M. Nadeem, K. R. Sadleir, J. Matras, C. M. Kelley, S. E. Counts, R. Vassar and E. J. Mufson, Int. J. Physiol., Pathophysiol. Pharmacol., 2012, 4(3), 115-127.

160 S. H. Eckert, J. Eckmann, K. Renner, G. P. Eckert, K. Leuner and W. E. Muller, J. Alzheimer's Dis., 2012, 31(1), 21-32.

161 M. N. Sabbagh and H. A. Shill, Curr. Opin. Invest. Drugs, 2010, 11(1), 80-91.

162 B. W. Miller, K. C. Willett and A. R. Desilets, Ann. Pharmacother., 2011, 45, 1416-1424.

163 P. A. Novick, D. H. Lopes, K. M. Branson, A. Esteras-Chopo, I. A. Graef, G. Bitan and V. S. Pande, J. Med. Chem., 2012, 55(7), 3002-3010.

164 M. Zhu, A. De Simone, D. Schenk, G. Toth, C. M. Dobson and M. Vendruscolo, J. Chem. Phys., 2013, 139(3), 035101.

165 L. Jiang, C. Liu, D. Leibly, M. Landau, M. Zhao, M. P. Hughes and D. S. Eisenberg, eLife, 2013, 2, e00857.

166 R. Scherzer-Attali, R. Pellarin, M. Convertino, A. FrydmanMarom, N. Egoz-Matia, S. Peled, M. Levy-Sakin, D. E. Shalev, A. Caflisch, E. Gazit and D. Segal, PLoS One, 2010, 5(6), e11101.

167 Y. Chebaro, P. Jiang, T. Zang, Y. Mu, P. H. Nguyen, N. Mousseau and P. Derreumaux, J. Phys. Chem. B, 2012, 116(29), 8412-8422.

168 T. Zhang, W. Xu, Y. Mu and P. Derreumaux, ACS Chem. Neurosci., 2014, 5(2), 148-159.

169 P. Nguyen and P. Derreumaux, Acc. Chem. Res., 2014, 47(2), 603-611.

170 O. Berthoumieu, P. H. Nguyen, M. P. Castillo-Frias, S. Ferre, B. Tarus, J. Nasica-Labouze, S. Noël, O. Saurel, C. Rampon, A. J. Doig, P. Derreumaux and P. Faller, Chemistry, 2015, 21(36), 12657-12666.

171 Z. Yang, C. Ge, J. Liu, Y. Chong, Z. Gu, C. A. Jimenez-Cruz, Z. Chai and R. Zhou, Nanoscale, 2015, 7(44), 18725-18737.

172 T. Zhang, J. Zhang, P. Derreumaux and Y. Mu, J. Phys. Chem. $B, 2013,117(15), 3993-4002$.

173 M. Dong, H. Li, D. Hu, W. Zhao, X. Zhu and H. Ai, ACS Chem. Neurosci., 2016, 7(5), 599-614.

174 A. J. Doig and P. Derreumaux, Curr. Opin. Struct. Biol., 2015, 30, 50-56. 
175 M. Ray, J. Ruan and W. Zhang, Genome Biol., 2008, 9(10), R148.

176 R. Leon, A. G. Garcia and J. Marco-Contelles, Med. Res. Rev., 2013, 33(1), 139-189.

177 Y. Zhu, K. Xiao, L. Ma, B. Xiong, Y. Fu, H. Yu, W. Wang, X. Wang, D. Hu, H. Peng, J. Li, Q. Gong, Q. Chai, X. Tang, H. Zhang, J. Li and J. Shen, Bioorg. Med. Chem., 2009, 17(4), 1600-1613.

178 M. Rosini, V. Andrisano, M. Bartolini, M. L. Bolognesi, P. Hrelia, A. Minarini, A. Tarozzi and C. Melchiorre, $J$. Med. Chem., 2005, 48(2), 360-363.

179 H. Liu, F. Liang, W. Su, N. Wang, M. Lv, P. Li, Z. Pei, Y. Zhang, Q. Xie, L. Wang and Y. Wang, J. Ethnopharmacol., 2013, 147(2), 366-372.

180 H. Chu, A. H. Zhang, Y. Han, S. Lu, L. Kong, J. Han, Z. D Liu, H. Sun and X. J. Wang, J. Chromatogr. B: Anal. Technol. Biomed. Life Sci., 2016, 1015-1016, 50-61.

181 A. Zhang, H. Sun and X. Wang, Mass Spectrom. Rev., 2016, 9999, 1-14.

182 L. Wang, C. Ma, P. Wipf, H. Liu, W. Su and X. Q. Xie, AAPS J, 2013, 15(2), 395-406.

183 H. Liu, L. Wang, M. Lv, R. Pei, P. Li, Z. Pei, Y. Wang, W. Su and X. Q. Xie, J. Cheminf., 2014, 54(4), 1050-1060.

184 H. Chu, A. Zhang, Y. Han and X. Wang, World J. Tradit. Chin. Med., 2015, 1, 26-32.
185 A. Zhang, H. Sun, S. Qiu and X. Wang, J. Evidence-Based Complementary Altern. Med., 2013, 2013, 257909.

186 X. Wang, A. Zhang, H. Sun, Y. Han and G. Yan, TrAC, Trends Anal. Chem., 2016, 76, 86-94.

187 A. Zhang, H. Sun and X. Wang, Phytother. Res., 2014, 28(4), 526-533.

188 X. Wang, A. Zhang, G. Yan, Y. Han and H. Sun, TrAC, Trends Anal. Chem., 2014, 63, 180-187.

189 H. Chu, H. Sun, G. Yan, A. Zhang, C. Liu, H. Dong, X. Meng and X. Wang, World Journal of Traditional Chinese Medicine, 2015, 1(3), 1-12.

190 Q. Liu, A. Zhang, L. Wang, G. Yan, H. Zhao, H. Sun, S. Zou, J. Han, C. W. Ma, L. Kong, X. Zhou, Y. Nan and X. Wang, Sci. Rep., 2016, 6, 38437.

191 X. Wang, A. Zhang, X. Zhou, Q. Liu, Y. Nan, Y. Guan, L. Kong, Y. Han, H. Sun and G. Yan, Sci. Rep., 2016, 6, 18997.

192 X. H. Zhou, A. H. Zhang, L. Wang, Y. L. Tan, Y. Guan, Y. Han, H. Sun and X. J. Wang, Chin. J. Nat. Med., 2016, 14(8), 561-581.

193 A. H. Zhang, H. Sun, G. L. Yan, P. Wang, Y. Han and X. J. Wang, China J. Chin. Mater. Med., 2015, 40(4), 569-576.

194 X. J. Wang, A. H. Zhang, H. Sun and G. L. Yan, Chin. Herb. Med., 2016, 8(4), 299-307.

195 A. Zhang, Q. Liu, H. Zhao, X. Zhou, H. Sun, Y. Nan, S. Zou, C. W. Ma and X. Wang, Sci. Rep., 2016, 6, 19333. 